\title{
RESOURCES REQUIRED IN CLINICAL PATHWAY FOR TYPHOID FEVER TREATMENT AT KALIWATES GENERAL HOSPITAL IN 2017
}

\author{
Sumber Daya dalam Clinical Pathway Perawatan Demam Typhoid \\ di Rumah Sakit Umum Kaliwates Tahun 2017
}

\author{
Pratiti Swesti Komala Dewi ${ }^{1}$, ${ }^{*}$ Christyana Sandra ${ }^{2}$, Eri Witcahyo ${ }^{3}$ \\ ${ }^{1}$ Institute of Tropical Disease, Indonesia \\ ${ }^{2,3}$ Faculty of Public Health, Universitas Jember, Indonesia \\ ${ }^{*}$ Correspondence: christyana_sandra@yahoo.com
}

\begin{abstract}
Background: A clinical pathway is a concept of an integrated service which describes the stages of healthcare services from the admission until the return of patients based on the medical service standards and evidencebased nursing care with measurable results. Kaliwates General Hospital is an accredited hospital with a clinical pathway. Typhoid case was the highest disease in 2017 at Kaliwates General Hospital.

Aims: This study aims to describe the resources at Kaliwates General Hospital in the implementation of clinical pathways, especially typhoid fever treatment.

Method: This study was a descriptive and qualitative study. Nine respondents were selected using purposive sampling, including one internist and the quality team at Kaliwates General Hospital. The variables studied include human resource factors, budget factors, method factors, and time factors.

Results: The results suggested that the human resources at Kaliwates General Hospital had high commitment, motivation, and moderate knowledge in the implementation of clinical pathways. All equipment and documents were considered adequate. The communication among the implementers was good, but compliance and training for staffs were considered less prominent. The task division of each staff was fairly distributed even though the pharmacy unit perceived that the division was quite unfair.

Conclusion: The implementation of the clinical pathway for typhoid fever treatment at Kaliwates General Hospital runs quite well. The hospital must identify and plan staff training regularly, prepare the job description appropriately, and perform performance appraisal based on the job description that has been developed.
\end{abstract}

Keywords: clinical pathway, typhoid fever, resource.

\section{ABSTRAK}

Latar Belakang: Clinical Pathway adalah konsep pelayanan terpadu yang menggambarkan tahap-tahap penting pelayanan kesehatan yang diberikan mulai saat penerimaan hingga pemulangan pasien berdasarkan standar pelayanan kedokteran dan asuhan keperawatan berbasis bukti dengan hasil yang terukur. RSU Kaliwates merupakan rumah sakit yang telah terakreditasi dan memiliki clinical pathway. Kasus typhoid merupakan kasus penyakit tertinggi pada tahun 2017 di RSU Kaliwates.

Tujuan: Tujuan penelitian ini untuk mengkaji sumber daya di RSU Kaliwates dalam implementasi clinical pathway khususnya perawatan demam typhoid.

Metode: Jenis penelitian ini adalah deskriptif kualitatif. Sembilan subjek penelitian dipilih menggunakan purposive sampling, meliputi satu orang dokter spesialis penyakit dalam dan tim mutu di RSU Kaliwates. Variabel yang diteliti adalah factor sumber daya manusia, faktor budget, faktor metode dan faktor waktu.

Hasil: Hasil penelitian menunjukkan bahwa SDM di RSU Kaliwates memiliki komitmen dan motivasi yang tinggi serta dikategorikan memiliki pengetahuan yang sedang dalam implementasi clinical pathway. Seluruh peralatan dan dokumen sudah memadai. Komunikasi antar pelaksana dalam kategori baik. Bentuk kepatuhan serta pelatihan bagi staf tidak diperhatikan. Pembagian tugas masing-masing staf sudah merata meskipun bagian farmasi merasa pembagian tugas belum cukup adil.

Kesimpulan: Implementasi clinical pathway perawatan demam typhoid di RSU Kaliwates berjalan cukup baik. Rumah sakit harus mengidentifikasi dan merencanakan pelatihan bagi staf secara berkala, penyusunan job description secara tepat, serta melakukan penilaian kinerja berdasarkan job description yang telah disusun.

Kata kunci: clinical pathway, demam typhoid, sumber daya. 


\section{INTRODUCTION}

Hospital must provide safe, quality, nondiscriminatory, and effective services by prioritizing the interests of patients under hospital service standards. The most crucial goal in health care is beneficial outcomes for patients and communities. The desired outcomes depend on the quality of health or hospital services (Fitri and Sundari, 2018).

The national health insurance in various countries requires health service which is supported by human resources, infrastructure, and the assistive devices for quality control and cost control (Chua and Cheah, 2012). The most crucial goal of health services is to provide beneficial outcomes for patients, providers, and communities that depend on the quality of health services in the hospitals (Hatta, 2008). Various regulations on health services in Indonesia have set standards on the implementation of the quality control system for health insurance services, i.e., input, process, and output. Process standards include clinical care management processes. The management processes, among others, are regulated in accreditation standards (Hospitals, Laboratories, Primary Health Care), excellent service standards, and so forth. Besides, clinical process (clinical care) is regulated in medical service guidelines and the standards of nursing care or generally referred to as clinical guidelines. One of the clinical guidelines is the clinical pathway that has the potential to be used as a tool to guarantee and improve the quality of the clinical care process (Fitri and Sundari, 2018).

According to Indonesian Law Number 44 of 2009 concerning Hospitals, realizing Universal Health Coverage (UHC) and hospital accreditation are the obligations that must be carried out by an Advanced Referral Health Facility or Fasilitas Kesehatan $R u$ jukan Tahap Lanjut (FKRTL) or hospital. In 2012, based on the hospital accreditation assessment by Hospital Accreditation Committee or Komite Akreditasi Rumah Sakit (KARS), hospitals expecting to apply for accreditation were required to have a minimum of 5 clinical pathways (Hospital Accreditation Committee, 2017).

A clinical pathway is in line with the aim of hospital accreditation in which hospitals are expected to be more efficient and have high accountability which makes clinical pathways as the alternatives for quality control and cost control (Ismawardani et al., 2014). Those are the key elements that must be accomplished to achieve the success of the clinical pathway. A vital result of the project was the identification of five distinct and sequential stages. These stages are defined as 1) the increase of awareness and commitment 2) the development of the system for implementing the clinical pathway 3) documentation (and designation) 4) implementation (trial, implementation, and development) 5) evaluation. Clinical pathway is an integrated service concept that describes in detail the stages of health services provided from the time of admission to the discharge of patients based on medical service standards and evidence-based nursing care with measurable results. Also, the clinical pathway is a part of documents and tools in realizing good clinical governance in hospitals (Wijayanti, 2016).
Based on data from Jember Social Security Agency for Health or Badan Penyelenggara Jaminan Sosial Kesehatan (BPJS Kesehatan) in the control report on inefficiency of hospital claim costs during 2016, there were 14 hospitals that experienced cost inefficiency. One of the hospitals that experienced cost inefficiencies was Kaliwates General Hospital, which ranked 7th in hospitals with cost inefficiencies in 2016 of IDR $181,425,000$. The Kaliwates General Hospital is a hospital that has been accredited $A$ level and has a clinical pathway. The approved clinical pathway is a clinical pathway for typhoid, heart failure, diarrhea, dengue hemorrhagic fever, and sectio-cesarea.

Based on medical record data at Kaliwates General Hospital obtained from the ten highest diseases at Kaliwates General Hospital in 2016, the number of hospitalized patients from January 2017 to March 2017 reached 512 patients. There were 109 or $21.28 \%$ of 512 patients hospitalized due to typhoid cases. The data indicated that typhoid case was the highest number of disease and, consequently it became a priority case that required the improvement of quality control and cost control.

The typhoid clinical pathway at Kaliwates General Hospital was implemented in June 2017 as an effort to improve the quality of care for typhoid patients. The implementation of the typhoid clinical pathway will not run well if it is not accompanied by readiness from the hospital and the implementers, medical personnel who specifically play a role in the implementation of the clinical pathway. System input are needed for the application of health services (Azwar, 2010). The condition of human resources also affects the outcome of the desired goals. Human resources are vital in organizational assets. Therefore, their roles and functions cannot be replaced by other resources. Even if modern technology is applied, or no matter how much funds are prepared, without professional human resources, it becomes meaningless (Handoko, 2012). According to this situation, this study aimed to review the resources at Kaliwates General Hospital in implementing clinical pathways for typhoid fever treatment.

\section{METHOD}

This research was a descriptive research that employed purposive sampling to select subjects. The respondents in this study consisted of nurses, medical records, internists, quality team, head of inpatient rooms, pharmacists, nutritionists, and laboratorists at Kaliwates General Hospital.

The variables used in this study were human resource factors in the form of commitment, knowledge, and motivation of Kaliwates General Hospital staff involved, budget factors, i.e., budget provided, equipment/material factors including supporting equipment and supporting documents, method factors included communication among implementers, compliance of the implementers, task division of the implementers, as well as trainings that had been followed, and minutes/time factors, namely time limit set by Kaliwates General Hospital in the implementation of clinical pathways for typhoid fever treatment. The primary data collected from interviews with medical staff, while the secondary data obtained through retrieving medical record data of typhoid 
clinical pathway, supporting documents for the implementation of a clinical pathway for typhoid fever treatment, SOP, and decrees issued by the Kaliwates General Hospital. The data obtained were analyzed univariately. In addition, the presentation of data from interview guides, the results of observations, and reviews of documents were displayed in narrative.

\section{RESULTS AND DISCUSSION}

\section{The Distribution of Human Resources in the Implementation of Clinical Pathway for Typhoid Fever Treatment at Kaliwates General Hospital}

Human resources are components involved in the implementation of programs and hold a vital role in an organization. Therefore, their parts and functions cannot be replaced by other resources. The variables of human resources studied, i.e., knowledge, commitment, and motivation. The data collection about human resources was obtained by collecting answers from questionnaires and documentation studies.

\section{Commitment}

The commitment was an attitude of a willingness of human resources to implement clinical pathways for typhoid fever treatment. Organizational commitment is a behavioral dimension that can be used to assess the tendency of employees to survive as members of the organization. Organizational commitment is the identification and involvement of someone who is relatively strong towards the organization. Organizational commitment is the desire of corporate members to maintain their membership in the organization and their willingness to strive for the achievement of organizational goals (Sopiah, 2008).

In the research questionnaires, the questions posed included the staff supports when the leader determined typhoid case as a service that would use clinical pathways, the staff's roles in the implementation of clinical pathways, staff's compliance with the Clinical Practice Guidelines or Panduan Praktis Klinis (PPK), the willingness of staff to be involved in the development of clinical pathway implementation, the staff's loyalty in the execution of tasks, the staff's supports for leaders who emphasized the implementation of clinical pathways, and the staff's compliance in the application of clinical pathways.

According to the results of the study, it was found that the respondents had a high commitment reached $75 \%$. The highest results were obtained from the willingness of staff to be involved in the efforts of developing clinical pathways and evaluating their implementation. However, some respondents stated that some staffs did not actively work on the clinical pathway reports. One of them was the medical record technician who never checked the completeness of the clinical pathway report that had been prepared by the staff.

This result is supported by the research conducted by Chua and Chech (2012), which states that the formation of organizational commitment is required in the implementation of clinical pathways in hospitals. Commitment is an effort to unite perceptions and agreements, as well as shared determination to achieve a goal (Chua and Cheah,
2012). The theory of George C. Edward III suggests that policy implementation is influenced by four variables, one of which is commitment (Subarsono, 2006).

The results of the study indicated that there were respondents as implementers of the clinical pathway supported the implementation of clinical pathways in Kaliwates General Hospital to improve services further and to fulfill commitments as accredited hospitals. These aspects were in line with the implementation of clinical pathways which were also meant to realize the goals of hospital accreditation, including to improve hospital patient safety, and protection for patients, communities, and hospital resources (Hospital Accreditation Committee, 2017). Commitment could also arise because of the leaders at Kaliwates General Hospital, which considered the implementation of clinical pathways. This study is supported by the research of Hidayati, which states that leadership directly influences organizational commitment (Hidayati et al., 2014). The absence of physician commitment, clinical leadership, and clinical management support are the aspects that impede the implementation of clinical pathways (Iriani, 2010).

\section{Knowledge}

This study based on respondents' knowledge was measured by questions about the understanding of clinical pathways, the purpose of clinical pathways, the benefits of clinical pathways, the main components in clinical pathways, supporting documents, and reference documents for the implementation of clinical pathways. There were seven respondents (77.8\%) with moderate knowledge about the clinical pathways. The results of the study indicated that 2 out of 9 respondents had low knowledge about the clinical pathways. The two respondents did not understand the clinical pathway and stated that they only carried out the SOP of the clinical pathway implementation.

A clinical pathway is a significant opportunity to narrow the evidence on gap practice in specific clinical settings. Given their interprofessional and typically hospital-based nature, the integration of clinical pathways into these settings involves complex interventions (Jabbour et al., 2013). Suhartini states that the higher and better the knowledge is, the employees' performance will increase as well, and vice versa (Suhartini, 2011). Organizational performance from individual aspects becomes essential because individuals must have knowledge that is relevant to their works (Kuncoro, 2013). From the results of the study, two respondents had low knowledge about the clinical pathways. According to Notoatmodjo, the intensity or level of one's experience of a particular object is not equal (Notoadmodjo, 2012).

\section{Motivation}

Motivation is an encouragement from within the respondents to be able to implement the clinical pathway in any situation. According to Dirgagunarsa (1996), motivated behavior can be formulated as behavior in the background by the existence of needs and directed at achieving a goal, therefore a requirement is fulfilled and a desire is satisfied 
(Manullang, 2012). There are three kinds of motivation, i.e., need for achievement, need of power, and the need to an affiliate or have close relations with others (need for affiliation). One way to measure motivation through a questionnaire is to ask clients to fill out a survey that contains questions that can provoke clients' motivation (Notoadmodjo, 2012).

Motivation was measured through
questionnaires about staff initiatives in carrying out tasks related to clinical pathways, encouraging to do a task for clinical pathways, work performance, willingness to work overtime if needed and attending a coordination meeting, being responsible for clinical pathway implementation. The employees' motivation could also be seen from how they used the clinical pathway tasks to develop their positions or careers. The questionnaires were a development of the three types of needs proposed by John W. Atkinson.

The respondents' motivation had reasonable motivation which was equal to $55.6 \%$. The respondents with moderate motivation were respondents who play an active role in making up to escort in the clinical pathway at Kaliwates General Hospital so that they could be more responsible for working optimally. The implementation of clinical pathways had no individual performance assessment. This aspect caused a respondent had low motivation because of the assumption that the work assignment was not possible to develop a career or position at Kaliwates General Hospital.

Based on the results of the study, it suggested that the motivation of employees in the implementation of clinical pathways for typhoid fever treatment was affected by the opportunity for career development or position. The motivation of respondents examined in this study according to Iriani included in intrinsic motivation, namely motivation or encouragement that appeared from within the individuals without any coercion from others, but by their own volition (Iriani, 2010). This study results were from the motivation of employees that was influenced by the opportunity for their career development or position. The results of this study were in line with Edwin Locke (1984) which states that intrinsic motivational factors can influence opportunities for promotions that can improve one's performance because it is measured by their opportunities for promotion (Robbins and Judge, 2012). The statement reinforces the results of research that low motivation of the respondents is caused by the presumption that the work assignment is not possible to develop a career or position at Kaliwates General Hospital.

Based on the results of the study, the respondents with moderate motivation were the respondents who played an active role in making up to escort in the clinical pathway at Kaliwates General Hospital so that they could be responsible for working as well as possible. This result is also in line with a study conducted by Hasibuan which states that one of factors that influence intrinsic motivation is responsibility. Responsibility is defined as demands to employees as placed in work units to carry out work by their duties (Hasibuan, 2011).
The Budget Distribution in the Implementation of Clinical Pathway for Typhoid Fever Treatment at Kaliwates General Hospital

Budget design can be used as a guideline for the implementation of organizational activities. The existence of a budget will make the organizational activities more focused and not deviated from the original goals. Budget is a control and evaluation tool because budget is prepared by considering experience, the current situation, and future forecasting which can be both short-term and longterm oriented. Hence, the budget is also able to act as an early warning tool for the existence of efficiency and effectiveness in the organization (Richardo, 2013). The budget factor is determined by budget availability and the cost factor for the implementation of clinical pathways for typhoid fever treatment at Kaliwates General Hospital. Based on the results of the study, it could be perceived that the availability and adequacy of the budget in the implementation of clinical pathways had been fulfilled. The clinical pathway implementation budget was included in the work program of the medical record section funded in the hospital's budget plan.

According to Rudianto, budget is an organizational work plan that is manifested in quantitative, formal, and systematic forms (Rudianto, 2013). Based on the results of the study, the availability and adequacy of the budget in the implementation of clinical pathways could not be categorized because Kaliwates General Hospital did not provide a budget. The budget was generally used in the preparation of plans and control systems, but it could also be used to coordinate, communicate, evaluate, motivate, and it could be used as a means of delegating superior authority to subordinates (Hansen and Mowen, 2012).

The Distribution of Equipment/Materials in the Implementation of Clinical Pathway for Typhoid Fever Treatment at Kaliwates General Hospital

The availability of equipment/materials was measured from the adequacy and the complete documents owned by Kaliwates General Hospital to support the implementation of the clinical pathway for typhoid fever treatment.

\section{Equipment}

The equipment in this study was defined as the availability and feasibility of the tools needed in the implementation of clinical pathways for typhoid fever treatment. In the research questionnaires, the questions asked included the availability, and feasibility of stationery, paper forms, and diagnostic support laboratories at Kaliwates General Hospital. The data collection on the equipment of the respondents were obtained by collecting answers from questionnaires and documentation studies.

Based on the results, it suggested that the equipment for the implementation of clinical pathways for typhoid fever treatment at Kaliwates General Hospital was completely adequate. The equipment in diagnostic support laboratories used in the implementation of clinical pathways for typhoid fever treatment utilized the same equipment for broader testing. Meanwhile, the Widal test is the most 
appropriate and fastest test to be applied to patients treating typhoid fever at Kaliwates General Hospital. However, this aspect was contradicted by the clinical practice guidelines in primary health care facilities (Pinzon, 2014). It is explained that the Widal test was not recommended in examining patients with Typhoid fever. False-positive Widal reaction frequently occured due to cross-reactions with nontyphoidal Salmonella, Enterobacteria, endemic areas of dengue infection and malaria, history of typhoid immunization, and varying commercialization of commercial antigen preparations. Widal test was not recommended for only one acute serum examination because it could lead to high false-positives, over-diagnosis, and overtreatment so that the hospital should replace diagnostic support tests for typhoid patients.

\section{Document}

Documents in this study were the availability of files including Clinical Practice Guidelines/Standard Operating Procedures for typhoid fever, Minimum Service Standards (SPM), Nursing Care Standard (SAK), length of stay analysis for typhoid patients, list of costs for typhoid fever care, and a list of supporting tests diagnostic for typhoid fever treatment. All of those documents was considered sufficient. However, this study found that Kaliwates General Hospital did not have the Nursing Care Standards document. In the hospital accreditation standard, it is known that not only clinical pathway documents but also the implementation of quality control and costs are an equally important factor (Hospital Accreditation Committee, 2017).

In this instance, briefing sessions with the doctors and nurses helped to erase some of the worrisome features in using clinical practice guidelines and pathways. In addition, putting down a legal disclaimer on the clinical pathway document and advising that interventions which can be changed according to the patients' clinical condition make the use of such forms more acceptable to the clinicians (Cheah, 2000).

\section{Distribution Method in Implementation of Clinical Pathway for Typhoid Fever Treatment at Kaliwates General Hospital}

In terms of distribution method, the management and implementers of Kaliwates Distritc Hospital used some variables in efficient implementation of the clinical pathway for typhoid fever treatment. The sub-variables studied included communication among implementers, rewards, task division, and prior training.

\section{Communication}

Communication among implementers in this study was a way the implementers interacted in the clinical pathway for typhoid fever treatment implementation at Kaliwates General Hospital. The communication among implementers was assessed through questions including the management clarity in providing work instructions, the staff's understanding of the contents of the clinical pathway form, the presence or absence of two-way communication among implementers, and the success of communication method applied. It was known that communication among implementers was reached
$55.6 \%$. The comparison of communication results among implementers who created excellent communication and who were lack of communication signified only a slight difference. The respondents with excellent communication did not communicate directly with the doctor in charge of service. Communication among some doctors was less cooperative because some doctors had their standpoint and different characters so that they can create a lack of two-way communication. According to Setiyanti (2012), the organizational success is strongly influenced by the capabilities and competencies of each and the collaboration among team members in the organization. In establishing cooperation to achieve these goals, communication is required.

George C. Edward III suggests that policy implementation is influenced by four variables, one of which is communication. Without communication, the work will be confusing and chaotic so that the goals of the organization are unlikely to be achieved. Hence, with communication, ones will receive news and information by what is in their mind or emotion so that others can understand (Subarsono, 2006).

Evans-Lacko et al. (2010) explains that the purpose of internal communication is to improve the performance of human resource in the organization. This communication occurs because there is a structure in the organization. The purpose of internal communication is to improve human resources performance in the organization (Evans-Lacko et al., 2010). Communication will work properly when mutual understanding arises. The good communication means that there is the fabric of understanding among one party to the others, thus, what is delivered can be understood, thought, and implemented. Without communication, the work will be confusing and chaotic, causing the goals of the organization to be seemingly not achieved (Effendy, 2006).

\section{Compliance Form}

The compliance structure in this study was the existence of rewards from management related to staff compliance behavior that played a role in implementing the clinical pathway according to the rules. Besides, it had discipline in the implementation of clinical pathways. Compliance can be in forms of rewards given to attentive staffs who perform their role well in the implementation of clinical pathways. It is proven that compliance by clinical pathway implementers at Kaliwates General Hospital was not considered by the management even though some respondents said that it did not require coercion to support the implementation of clinical pathways because it was related to the responsibility in the process.

\section{Task Division}

The task division is an equal distribution of work assignments so that each staff is responsible for implementing the clinical pathway. The task division are the work details containing comprehensive information about the duties/obligations, responsibilities, and the required conditions to make the work completed. The assignments in this study were assessed through questions about the fairness of tasks division and understanding of each staff's job description (Prawirosentono, 2010). The task division 
has been fairly distributed at $77.8 \%$. In the implementation of the clinical pathway, the staff implemented a shift system so that the clinical pathway continued to run for 24 hours. Also, the staff has understood the roles and job desk that each part must do.

It is identified that the unfair task distribution reached $22.2 \%$ because there was only one person in charge of multiple rooms and tasks. A good work situation means the existence of an appropriate task division and group affirmation of similar activities or, at least, have close correlation. It will ensure a smooth work implementation and provide optimal results for the organization (Murti and Iswati, 2014).

From the results of the respondent interviews, it was identified that the staff understood the job desk for each section. The staff understood their roles and responsibilities to minimize any misunderstanding between sections in the implementation of clinical pathways. According to Murti and Iswati (2014), with the task division, the people in an organization know what they have to do, their duties, functions, responsibilities, obligations, rights, authority and who are their superiors or subordinates.

\section{Training}

The training in this study included the staff participation in seminars and training as an effort to gain additional knowledge and skills in the implementation of clinical pathways. The training in this study was assessed based on questions about staff participation in training and seminars on clinical pathways and their presence or absence on the periodic staff training. Based on the research results, it was found that staff training was inadequate for all respondents at $100 \%$. Before the implementation of the clinical pathway, the staff who played the role in the implementation stated that there was only information dissemination of technical instructions about clinical pathways, which was given only from the quality team. This information dissemination also only invited the section heads to be later forwarded to their subordinates. The training on clinical pathways was only carried out by several doctors to make the initial clinical pathway.

Education and training can be seen as one form of investment. If an organization or agency wants to develop, education and training for its employees must receive attention to develop knowledge, attitudes, and work skills in their efforts to improve employee performance to produce quality products. The efforts to close the gap between the employees' performance and the work demands are required so that a mutually beneficial condition for both the agency and employees can be achieved (Widijanto, 2017).

\section{Study Period of Clinical Pathway Implementation for Typhoid Fever Treatment at Kaliwates General Hospital}

The time variable examined in this study is the time limit available for the execution of each task and evaluation of the implementation of clinical pathways. It is known that there was a time limit for quality and evaluation based on the questionnaire answers from 7 respondents $(77.8 \%)$. There were two parts $(22.2 \%)$ that did not have a time limit for quality and evaluation due to the absence of an evaluation of the two sections and evaluation were only carried out before the last accreditation. The purpose of scheduling activities was to reduce some slowness in the work with completion time limit to minimize penalty costs. Minimal monitoring and evaluation in the workplace are also one of the main obstacles to achieve the potential for organizational success (Ginting, 2009).

\section{CONCLUSION}

The human resources at Kaliwates General Hospital have high commitment, and motivation. Some respondents had sufficient knowledge in the implementation of clinical pathways. The budget availability and adequacy in the implementation of the clinical pathway have been fulfilled. All equipment and documents required and related to the implementation of clinical pathways for typhoid fever treatment at the Kaliwates General Hospital are sufficient. The communication among the implementers is catego rized as a useful aspect. The form of compliance and training for staff in implementing clinical pathways is not a concern for the management. The task division of each staff has been fairly distributed even though the Pharmacy Unit considers that the task division is unfair due to the lack of human resources. The deadline for the task and evaluation of a clinical pathway for typhoid fever treatment at Kaliwates General Hospital has followed the Standard Operating Procedures.

The hospital must identify the staffs who have moderate and less knowledge related to the implementation of clinical pathways to undergone staff training that can also be held regulary. The Human Resource division should arrange the job description appropriately so that the task division for each staff is fairly distributed. The Human Resource division should conduct performance assessments based on the job description. To improve the implementation, it would be better to involve the people that have enough power or top management to control the process of implementation, and evaluation, and information dissemination about clinical pathways to all the staffs involved.

\section{CONFLICT OF INTEREST}

The authors state that there is no conflict of interest in this article.

\section{REFERENCES}

Fitri, D. A. and Sundari, S. (2018) 'The Evaluation of Clinical Pathway Implementation on Cerebral Infarction in the Inpatient Care Unit of Bantul X Hospital', Jurnal Medicoeticolegal dan Manajemen Rumah Sakit, 7(2), pp. 152-161. doi: $10.18196 / \mathrm{jmmr} .7268$

Azwar, A. (2010) Pengantar Administrasi Kesehatan Edisi 3. Jakarta: Jakarta Binarupa Aksara.

Chawla, A. et al. (2016) 'Care Pathways in Us Healthcare Settings: Current Successes and Limitations, and Future Challenges', The American Journal of Managed Care, 22(1), pp. 53-62.

Cheah, J. (2000) 'Development and Implementatiton 
of a Clinical Pathway Programme in an Acute Care General Hospital in Singapore', International Journal for Quality in Health Care, 12(5), pp. 403-412. Available at: http://ovidsp.ovid.com/ovidweb.cgi?T=JS\&PAG $E=$ reference \&D=emed5\&NEWS $=\mathrm{N} \& A N=11026$ 801.

Chua, H. T. and Cheah, J. C. H. (2012) 'Financing universal coverage in Kenya - A Case Study', International Journal of Biomedical Research, 12(Suppl 1), p. $849 . \quad$ doi: 10.7439/ijbr.v6i10.2577.

Effendy, O. U. (2006) IImu Komunikasi: Teori dan Praktek. Bandung: PT Remaja Rosdakarya.

Evans-Lacko, S. et al. (2010) 'Facilitators and Barriers to Implementing Clinical Care Pathways', $B M C$ Health Services Research, 10(182), pp. 1-6. Available http://www.biomedcentral.com/1472 6963/10/182.

Ginting, R. (2009) Penjadwalan Mesin. 1st edn. Yogyakarta: Graha Ilmu.

Handoko, T. H. (2012) Manajemen. 2nd edn. Yogyakarta: BPFE.

Hansen, D. R. and Mowen, M. M. (2012) Akuntansi Manajerial. 8th edn. Jakarta: Salemba Empat.

Hasibuan, S. P. (2011) Manajemen Sumber Daya Manusia. Jakarta: Bumi Aksara.

Hatta, G. R. (2008) Pedoman Manajemen Informasi Kesehatan di Sarana Pelayanan Kesehatan. Jakarta: UI Press.

Hidayati, A. et al. (2014) 'The Development of Character Education Curriculum for Elementary Students In West Sumatera', International Journal of Education and Research, 2(6), pp. 189-198.

Hospital Accreditation Committee (2017) Standar Nasional Akreditasi Rumah Sakit. 1st edn. Jakarta: Kementerian Kesehatan RI.

Iriani, N. I. (2010) 'Motivasi Intrinsik, Motivasi Ekstrinsik dan Disiplin Kerja Pengaruhnya terhadap Kinerja Pegawai pada Kantor Dinas Pendidikan Kabupaten Sambas', Jurnal Aplikasi Manajemen, 8(2), pp. 561-569.

Ismawardani, D. et al. (2014) 'INA CBGs Membuat Biaya Kesehatan Lebih Efektif Edisi VIII', InfoBPJS Kesehatan.

Jabbour, M. et al. (2013) 'Best strategies to implement clinical pathways in an emergency department setting: Study protocol for a cluster randomized controlled trial', Implementation Science, 8(55), pp. 1-11. doi: 10.1186/1748-5908-8-55.

Kuncoro, M. (2013) Mudah Memahami dan Menganalisis Indikator Ekonomi. Yogyakarta: UPP STIM YKPN

Manullang, M. (2012) Dasar-Dasar Manajemen. Yogyakarta: Gajah Mada University.

Murti, E. and Iswati, R. (2014) 'Pembagian Kerja terhadap Efektifitas Organisasi Publik di Desa Karangrejo Kecamatan Kendal Kabupaten Ngawi', Jurnal Sosial, 15(2), pp. 1-15.

Notoadmodjo, S. (2012) Promosi Kesehatan Dan Perilaku Kesehatan. Jakarta: Rineka Cipta.

Pinzon, R. T. (2014) Clinical Pathway dalam Pelayanan Kesehatan. Yogyakarta: Pustaka Cendekia Press.

Prawirosentono (2010) Manajemen Sumber Daya
Manusia: Kebijakan Kinerja Karyawan: Membangun Organisasi Kompetitif Era Perdagangan Bebas Dunia. 2nd edn. Yogyakarta: BPFE.

Richardo (2013) Analisis Anggaran sebagai Alat Perencanaan dan Pengendalian Biaya pada CV WIDIA MAS di Pelalawan. Undergraduate Thesis. Universitas Islam Negeri Sultan Syarif Kasim.

Robbins, S. and Judge, T. A. (2012) Perilaku Organisasi. 2nd edn. Jakarta: Salemba Empat.

Rudianto (2013) Akuntansi Manajemen: Informasi untuk Pengambilan Keputusan Strategis. Jakarta: Erlangga.

Setiyanti, S. W. (2012) 'Membangun Kerjasama Tim (Kelompok)', Jurnal STIE Semarang, 4(3), pp. 59-65.

Sopiah (2008) Perilaku Organisasional. Yogyakarta: Andi Press.

Subarsono, A. G. (2006) Analisis Kebijakan Publik: Konsep, Teori dan Aplikasi. Yogyakarta: Pustaka Pelajar.

Suhartini, Y. (2011) 'Faktor-Faktor yang Mempengaruhi Minat Mahasiswa dalam Berwiraswasta (Studi pada Mahasiswa Universitas PGRI Yogyakarta)', Jurnal Akmenika UPY, 7, pp. 38-59.

Widijanto, K. A. (2017) 'Pengaruh Pelatihan Kerja dan Motivasi Kerja Terhadap Kinerja Karyawan Divisi Pemasaran di PT Sumber Hasil Sejati Surabaya', Agora, 5(1), pp. 1-5.

Wijayanti, F. E. (2016) Analisis Clinical Pathway dengan BPJS antara RS Negeri dan RS Swasta. Postgraduate Dissertation. Universitas Muhammadiyah Surakarta. 